\title{
KRITIK TERHADAP PEMIKIRAN ABDULLAHI AHMED AN-NA'IM TENTANG KONSEP WARIS BAGI NON MUSLIM
}

\author{
Nuril Habibi \\ Institut Pesantren KH. Abdul Chalim Mojokerto \\ Email: habibi.lfaqir@gmail.com
}

\begin{abstract}
This research will explain and classify the thoughts of Abdullah Ahmed an-Na'im, his thinking there are pros and cons, where he seeks to present the legal order based on Islamic norms and values in contemporary life. This clearly shows Abdullah Ahmed an-Na'im's concern for the continued application of Islamic values in the face of the demands of modernization. The study that becomes Abdullah Ahmed an-Na'im's concern is the issue of Shari'a versus Human Rights in terms of its epistemology. The thinking can be classified as a liberal study because the methodological framework used is like the general rules used by the secularists. Rational and scientific validity are used as measures to determine the truth and human values are used as goals by ignoring the divine value. Even an-Na'im deny the role of the main sources of Islamic law, namely the Qur'an and Hadith. This can be seen clearly in his attitude which tends to ignore the important role of the Shari'a on human rights but on the other hand the role of secular law is considered to be so dominant and "great" in solving international human rights issues. Especially the case of non-Muslims in Islamic inheritance. The system of inheritance according to the Qur'an and the hadith and explained by the scholars in the classical books is final. Obeying the distribution of inheritance is a form of ta'abudi from a servant to his Rabb.
\end{abstract}

Keywords: Abdullah Ahmed an-Na'im, Human Rights, Inheritance.

\section{ABSTRAK}

Penelitian ini akan menjelaskan dan mengkirtisi pemikiran Abdullah Ahmed an-Na'im, pemikiranya terdapat adanya pro dan kontra, dimana dia berupaya untuk menghadirkan tatanan hukum yang dilandasi oleh norma-norma dan tata nilai Islam dalam kehidupan kontemporer. Hal ini secara jelas menunjukkan kepedulian Abdullah Ahmed an-Na'im terhadap keberlangsungan penerapan nilai-nilai Islam berhadapan dengan tuntutan modernisasi. Kajian yang menjadi konsen Abdullah Ahmed an-Na'im yaitu isu syariat versus HAM dilihat dari epistimologinya. Pemikiranya dapat dikelompokkan sebagai kajian yang liberal karena kerangka metodologi yang dipakai seperti kaidah yang umum digunakan oleh kaum sekuler. Keabsahan rasional dan saintifik dijadikan ukuran menentukan kebenaran dan nilai kemanusiaan dijadikan tujuan dengan mengesampingkan nilai ketuhanan. Bahkan an-Na'im menafikan peran sumber hukum Islam yang utama yaitu Alquran dan Hadis. Hal ini terlihat jelas pada sikapnya yang cenderung mengabaikan peran penting dari syariat tentang HAM tapi di sisi lain peran hukum sekuler dianggap begitu dominan dan "hebat"dalam memecahkan persoalan HAM internasional. Terutama kasus non muslim dalam kewarisan islam. Sistem kewarisan menurut al-Qur'an dan hadis serta dijelaskan oleh para ulama dalam kitab-kitab klasik sudahlah final. Mentaati pembagian waris merupakan bentuk ta'abudi dari seorang hamba kepada Rabbnya.

Kata kunci: Abdullah Ahmed an-Na'im, Hak Asasi Manusia, Waris.

\section{PENDAHULUAN}

Hak Asasi Manusia (HAM) adalah hak yang berkembang dari pemikiran modern eropa. Hak-hak ini terus berkembang di barat dan menjadi standar internasional-legal. 
Dengan Deklarasi Universal Hak-Hak Asasi Manusia (UDHR) ${ }^{1}$ Perserikatan BangsaBansa (PBB) hak ini sekarang telah menjadi hukum intenasioanl. ${ }^{2}$

Deklarasi universal hak-hak manusia di atas pada perkembangan selanjutnya menjadi fenomena yang sangat signifikan, terutama sebagai usaha untuk menterjemahkan keyakinan-keyakinan tentang martabat manusia ke dalam bahasa hukum yang konkrit. Ia merupakan peristiwa pertama dalam sejarah umat manusia, dimana seluruh bangsa di pelbagai penjuru dunia membuat Deklarasi tentang HAM dan kebebasan fundamental manusia. ${ }^{3}$

Eksistensi hak asasi manusia tidak dapat diterangkan secara memadai dari segi pengundangan dalam hukum (domestik/Internasional), tetapi Hak Asasi Manusia lebih tepat bila dipahami sebagai petunjuk atau kewajiban pemerintah maupun individu. Menurut Deklarasi Universal, kewajiban-kewajiban ini menyangga Hak Asasi Manusia di pelbagai bidang, termasuk perlindungan hukum, keamanan serta otonomi pribadi, partisipasi politik, persamaan dan kesejahteraan. ${ }^{4}$

Hak yang dideklarasikan di atas merupakan usaha yang dilakukan oleh negaranegara di dunia dengan tujuan perdamaian dan menghilangkan adanya diskriminatif terhadap warga negara yang bertempat tinggal di negara tersebut. Sebab dalam prinsip resiprositas universal menuntut bagi setiap warga negara saling memberlakukan dengan adil dan bijaksana. Dalam artian ketika kaum muslim mengklaim dan menggunakan hakhaknya, maka mereka juga harus mengakui dan menjamin hak-hak yang sama bagi orang lain. $^{5}$

Itulah salah satu faktor yang mendorong an-Na'im untuk menjadikan Deklarasi HAM sebagai premis utama untuk melandasi pendiriannya bahwa dalam kehidupan internasional yang telah ada standar universal tentang Hak Asasi Manusia yang harus

\footnotetext{
${ }^{1}$ UDHR singkatan dari The Universal Declaration Of Human Rights, Maulana Abul A'la Maududi, HakHak Asasi Manusia Dalam Islam, terj, Bambang Iriana Djaja atmadja, (Jakarta; Bumi Aksara, 2005), 49

${ }^{2}$ Bassam Tibi, Syari'ah, HAM, dan hukum Internasional, dalam Demokrasi Syari'ah II; Kritik Konsep Penjelajahan Lain, terj. Farid Wajidi, (Yogyakarta: LkiS, 1996), 85

${ }^{3}$ Harun Nasution dan Bahtiar Effendi (ed), Hak-Hak Asasi Manusia dalam Islam, ( Jakarta: Pustaka Firdaus, 1995), 75

${ }^{4}$ James W. Nickel, Hak Asasi Manusia, Releksi Filosofis Atas Deklarasi Universal Hak Asasi Manusia, terj. Titis Eddy Arini, (Jakarta: PT. Gramedia Pustaka Utama, 1996), 86

${ }^{5}$ Abdullahi Ahmed An-Na'im, Dekonstruksi Syari'ah Wacana Kebebasan Sipil, Hak Asasi Manusia dan Hubungan Internasional dalam Islam, terj. Ahmad Suaedy, 3
} 
ditaati oleh seluruh negara di dunia, tak terkecuali negara-negara islam. ${ }^{6}$ Menurutnya ada semacam kewajiban bersama untuk mempromosikan dan memperjuangkan hak-hak asasi manusia tanpa harus melihat perbedaan ras, jenis kelamin, bahasa, maupun agama.

Dalam syari' $\mathrm{hh}^{7}$ sendiri telah ada pendiskriminasian, yaitu ketidakikutsertaan dalam pembagian warisan bagi non muslim yang mempunyai keluarga atau sanak saudara yang berlainan agama dengannya. Hal ini telah terjadi di dunia muslim sejak perbedaan-perbedaan muncul tentang interpretasi terhadap naș-naṣ al-Qur'an dan hadiṣ yang dilakukan oleh ulama mazhab.

Salah satu sumber yang dijadikan ulama sebagai alasan utama atas sebab penghalang bagi non muslim dalam mendapatkan warisan ini adalah, hadiṣ Rasulullah yang artinya; "dari Usamah Bin Zaid bahwa Nabi telah bersabda: tidaklah berhak seorang muslim mewarisi orang kafir, dan tidak pula orang kafir mewarisi muslim.'”

Hadis di atas dijadikan sebuah kesepakatan (ijma') bagi ulama mazhab dalam memutuskan perkara tentang perbedaan agama yang menjadi penghalang utama dalam mendapatkan waris dari ahli waris yang lain agama dengannya.

Bagi an-Na'im, syari'ah yang ada sebagai hasil interpretasi ulama' dalam konteks abad ke-7 sampai ke-9 dalam beberapa aspek tertentu, diantaranya adanya sebab penghalang untuk mendapatkan bagian waris yaitu berbeda agama antara orang yang mewarisi dan yang diwarisi, hal ini sudah tidak memadai dan tidak mendukung, bahkan bertentangan dengan standar HAM. ${ }^{9}$ Formula syari'ah yang membolehkan penggunaan kekuasaan agresif dalam menyebarkan islam, perbudakan, dan perlakuan diskriminatif terhadap wanita dan non muslim, disebut-sebut sebagai contoh kasus pertentangan di atas. Demikian pula sanksi potong anggota tubuh dan rajam, yang dinilai kejam dan tidak menghormati martabat manusia.

Hal di atas adalah titik konflik dan ketegangan yang paling serius antara syari'ah dan Hak Asasi Manusia Universal, oleh sebab itu syari' ah yang sebagai pedoman umat muslim di seluruh dunia sudah tidak dapat berbicara sesuai dengan konteks kekinian.

\footnotetext{
${ }^{6}$ Ibid, 308-309

${ }^{7}$ Hukum-hukum yang ditetapkan dengan cara merujuk pada al-Qur'an dan sunnah

${ }^{8}$ Imam Muslim, Sahih Muslim, Juz 11, 44

${ }_{9}$ Abdullahi Ahmed an-Na'im, Dekosntruksi syari'ah..., 326
} 
Dan syari'ah juga perlu disesuaikan dengan standar HAM yang sebagai standar kehidupan internasional.

Problem umum ini menyebabkan adanya reinterpretasi terhadap al-Qur'an dan Sunnah dengan cara yang memungkinkan kita untuk menyingkirkan bentuk-bentuk diskriminasi terhadap perempuan dan non muslim.

Dengan fenomena di atas, maka mengupas dan menganalisis gagasan an-Na'im terutama berkaitan dengan HAM, kedudukan non muslim dalam kewarisan islam, merupakan kebutuhan yang mendesak untuk dikaji.

\section{SEKILAS RIWAYAT HIDUP ‘ABD ALLĀH AḤMAD AL-NATM}

Abdullahi Ahmed an-Na'im yang selanjutnya dikenal dengan an-Na'im. Ia lahir di Sudan, 19 Nopember 1946. Setelah menamatkan Sekolah Menengang Atas, an-Na'im melanjutkan studi S1 pada Fakultas Hukum, Jurusan Hukum Pidana di Universitas Khortoum, Sudan. ${ }^{10}$ Begitu menyelesaikan studinya, an-Na'im mengikuti kuliah di Universitas Cambridge, Inggris, dan menyandang gelar LL.B., dan menyelesaikan program doktornya dalam bidang Hukum, di Universitas Edinburgh, Skolandia. ${ }^{11}$

Kemudian, an-Na'im menjadi Dekan pada Fakultas Hukum di Univesitas Khortoum. Di tengah-tengah sebagai dekan, ia juga menyelesaikan pendidikan tambahan di Internasional Institut Of Human Rights di Stanbroug, Perancis pada musim panas tahun 1981. Di samping itu, ia melakukan studi banding tentang HAM di Colombia pada 1981-1982, dan kemudian kembali mengajar di Universitas Khotoum sampai an-Na'im ditahan oleh Pemerintah Numeyri pada tahun 1983, karena kritiknya terhadap penerapan syari'ah di Sudan. Namun setelah pemerintah Numeyri jatuh pada April 1985, an-Na'im mendapatkan penghargaan sebagai pembela HAM yang aktif. Sebagai seorang yang pernah menjadi pengacara yang gigih membela HAM sejak 1977, pada tahun 1985, an-Na'im mendapat kesempatan untuk menjadi Professor tamu dalam bidang Hukum di University Of California Los Angeles, Amerika Serikat. ${ }^{12}$

\footnotetext{
${ }^{10}$ Muhyar Fanani, Abdullahi Ahmed an-Na'im: Paradigma Baru Hukum Publik, Dalam Pemikiran Kontemporer, (Yogyakarta: Jendela, 2003). 3

${ }^{11}$ Charles Kruzman, Syari'ah dan Isu-Isu HAM, dalam Wacana Islam Liberal : Pemikiran Islam Kontemporer Tentang Isu-Isu Global, Terj. Bahrul Ulum, (Jakarta; Paramadina, 2001), 369.

${ }^{12}$ Muhyar fanani, Abdullahi Ahmed An-Na'im: Paradigma Baru hukum Publik, dalam pemikiran Islam Kontemporer, 4
} 
Selain itu, an-Na'im, pada Agustus 1988 sampai Januari 1991, ia menjadi professor tamu Ariel F. Sallows dalam bidang HAM di fakultas Hukum, Universitas Saskatchewan, Kanada. Pada Agustus 1991 sampai Juni 1992 menjadi professor tamu di Olof Palme pada Fakultas Hukum, University Of Upshala, Swedia dan sejak Juni 1995 menjadi professor hukum di Universitas Emory, Atlanta, GA, Amerika Serikat.

Dalam hidupnya, an-Na'im yang merupakan seorang generasi kontemporer dari akademisi dan juga aktivis muslim yang telah membina karier kerjasamanya dengan melibatkan diri dalam masalah-masalah sosial. Pengalamannya sabagai seorang mahasiswa dan pengacara yang tidak pernah lepas dari konflik yang ada di Sudan, membuatnya banyak menentang terhadap penerapan syari'ah yang diterapkan di negaranya. Dengan sebab kegelisahannya terhadap pemerintahan negara sudan, serta sifat kritisnya tehadap islam sendiri, membuat an-Na'im menulis untuk menentang dan memberikan kesadaran bagi rakyat Sudan.

Berangkat dari kegelisahan dan keinginan untuk menyadarkan rakyat Sudan, anNa'im menjadikan dirinya sebagai penulis yang produktif. Antara tahun $1974-1999$ ia telah menulis sekitar empat puluh artikel panjang, tujuh belas artikel pendek, book review dan buku. Di antara buku yang pertama ditulis an-Na'im adalah Sudene Criminal Law: The General Principles Of Criminal Responsibility, yang pada awalnya ditulis dalam bentuk bahasa arab, yang diterbitkan oleh Omdurman; Sudan Huriya Press, 1985. Sedangkan buku keduanya yang menumental dan bisa dianggap karya magnum opusnya yang berjudul Toward an Islamic Reformation: Civil Liberties, Human Rights and Internasional (Syracuse University Press, 1990). Buku ini diterjemahkan ke dalam bahasa Arab (1994) dan juga diterjemahkan ke dalam Bahasa Indonesia (1995) dengan judul Dekonstruksi Syari'ah: wacana Kebebasan Sipil, Hak Asasi Manusia dan Hubungan Internasional. ${ }^{13}$

Betapapun, karya-karya an-Na'im sebagian besar berbentuk makalah yang dibuatnya untuk keperluan seminar, tetapi karena isu yang diajukannya sangat mendasar dan kontroversial, maka popularitas an-Na'im menanjak dengan cepat bak meteor. Kapasitas keilmuan dan semangat reformasi yang dibawanya telah menempatkannya sebagai pemikir muslim yang diperhitungkan pada akhir abad ini. Dipublikasinya karya-

\footnotetext{
${ }^{13}$ Ibid, 5
} 
karya an-Na'im dalam berbagai jurnal ilmiah berskala internasional, selain menunjukkan betapa luasnya jaringan intelektual yang dibangunnya, juga merupakan bukti atas pengakuan masyarakat intelektual terhadapnya. ${ }^{14}$

Selain membina karier intelektualnya dan kesarjanaannya, an-Na'im aktif pula dalam kegiatan sosial politik dan keagamaan di Sudan bersama guru dan kelompoknya. Ketika Sudan diperintah oleh Jenderal Muhammad Ja'far Numeyri (1964-1985), ia melakukan gerakan oposisi. Gerakan ini mencapai klimaksnya ketika rezim Numeyri melancarkan gerakan Islamisasi dengan memberlakukan hukum islam sebagai hukum negara. ${ }^{15}$

Dalam perkembangan keintelektualnya, an-Na'im lebih banyak dipengaruhi dengan pendidikan dan bidang keilmuan yang ia geluti. Salah satu contoh yang ada dalam kehidupannya adalah dalam bidang HAM. Hal ini dengan jelas dapat dilihat dari karya-karya ilmiah dan isu-isu yang diangkat an-Na'im yang hampir seluruhnya berkisar pada seputar hukum islam dalam kaitannya dengan isu-isu internasional modern.

Selain sebagai ahli hukum dan ahli hubungan internasional, an-Na'im adalah sosok ilmuan yang langka karena mampu menggabungkan dua disiplin ilmu yang memiliki akar yang berbeda. Hukum islam yang berakar pada konteks sosio-kultural dinasti (Umayyah dan Abbasiyah) pada abad ke 7 hingga 13 M. Sedangkan hubungan internasional berakar pada konteks era nation-state dunia modern yang bersumber dari Eropa abad $17 \mathrm{M}$. Untuk itu, ia memilih hubungan internasional sebagai salah satu proyek pemabaruan hukumnya. ${ }^{16}$

\section{GENEOLOGI PEMIKIRAN HUKUM AN-NA'IM}

Untuk memahami pemikiran hukum an-Na'im tidak bisa dilepaskan dari bayangbayang Mahmud Muhammad Thaha, seorang tokoh modernis kontroversial yang juga merupakan guru an-Na'im semasa ia menjadi mahasiswa. Perkenalannya dengan Thaha dalam mengikuti perkuliahannya secara intens memberikan dasar pijak pemikiran hukum islam an-Na'im yang tidak taken for granted, dan upayanya dalam melakukan

\footnotetext{
${ }^{14}$ John L. Esposito, The Oxford Encyclopedia Of The Modern Islamic World, Vol. IV,ed. 299-300

${ }^{15}$ Mahmud Muhammad Thaha, Arus Balik Syari'ah, terj. Khairon Nadhiyin, 52

${ }^{16}$ Muhyar Fanany, Abdullahi Ahmed an-Na'im: paradigma Baru hukum Publik, dalam Pemikiran Kontemporer, 5
} 
reinterpretasi secara radikal terhadap pesan etik moral yang terdapat dalam al-Qur'an dan sunnah sebagai dua sumber normatif dalam ajaran islam.

Keterkaitan an-Na'im dengan pemikiran islam yang ditawarkan oleh Thaha ditunjukkan dengan mengikuti diskusi-diskusi informal di rumah Thaha. Diskusi-diskusi itu mengantarkan an-Na'im menjadi anggota formal republican brotherhood. ${ }^{17}$

Pada era 1960-an perbebatan politik di Sudan memang sangat tajam. Inilah yang membawa salah satu negara Islam di Benua Hitam Afrika itu selalu bergejolak. Ia merupakan contoh yang unik bagi kasus tarik menarik antara islam dan negara-bangsa (nation-state).

Sejak lepas dari cengkraman Inggris pada 1 Januari 1956, pencarian ideologi negara menjadi masalah mendasar yang tidak pernah kunjung selesai bagi masyarakat Sudan yang plural. Sepanjang sejarah perdebatan politik Sudan, tercatat ada 3 (tiga) kecenderungan pemikiran; pertama, keinginan untuk menjadikan Sudan sebagai Negara Islam dan berideologi Islam. Ini dimotori oleh Partai Persaudaraan Muslim (sekarang bernama NIF atau National Islamic Front) yang manjadi partai dominan di Sudan sejak 1986. Pencetus pemikiran ini adalah Hasan al-Turabi. ${ }^{18}$ Kedua, keinginan untuk menjadikan ideologi sekular inggris sebagai ideologi negara, dimotori oleh kekuatan kolonial. Ketiga, keinginan untuk menjadikan ideologi islam Modern yang menyetujui bentuk negara Republik, dimotori kaum Republik dengan tokohnya, Mahmud Muhammad Thaha.

Perdebatan sengit diantara ketiga kelompok itu sering dimanfaatkan oleh pemegang kekuasaan yang justru berasal dari kelompok militer. Salah satu rezim yang menggemparkan dunia pada tahun 1985 adalah presiden Numeyri yang juga seorang militer. Ia menggunakan politik islamisasi hukum Sudan untuk menumpas lawan-lawan politiknya. Di antara korban politik adalah Thaha.

\footnotetext{
${ }^{17}$ Abdullahi ahmed an-Na'im, Dekosntruksi syari'ah..., xi

${ }^{18}$ Hasan Abdullah Turabi lahir di Sudan 1 Februari 1932 dari keluarga muslim yang taat. Ia dididik baik secara tradisional maupun modern. Sejak mahasiswa pada tahun 1950-an, ia menjadi aktivis ikhwan alMuslimin cabang Sudan dan menjadi seorang aktor penting dalam setiap perkembangan politik besar di Sudan sejak tahun 1964. Lihat John L. Esposito, Tokoh Kunci Gerakan Islam Kontemporer, 137
} 
Dari gambaran singkat tersebut, terlihat bahwa pemikiran Thaha yang menjadi inspirator utama an-Na'im untuk membuat Islam berkompromi dengan negara-bangsa dan tidak menghendaki diskriminasi antar warga negara. ${ }^{19}$

Diskriminasi yang dilakukan oleh negara terutama di bidang hukum menjadi sorotan utama an-Na'im. Perlakuan diskriminatif penerapan hukum terhadap warga negara dilihat pada aplikasi hukum potong tangan yang diberlakukannya harus mendapat dukungan dari semua lapisan warga negara termasuk non muslim dan muslim sekuler, tidak hanya atas persetujuan mayoritas muslim saja.

Kebijakan ini menurut an-Na'im tidak ada tempatnya. Menurutnya penerapan syari'ah sendiri merupakan pemaksaan terhadap hak-hak asasi manusia karena syari'ah sendiri merupakan hasil interpretasi yang dilakukan oleh manusia yang kemudian dijadikan oleh negara sebagai undang-undang. Maksudnya adalah keseluruhan proses formulasi dan implementasi kebijakan dan perundang-undangan publik tunduk kepada kesalahan dan kekeliruhan manusia, dan hal ini, bagi an-Na'im masih bisa ditentang dan dipertanyakan tanpa melanggar kehendak Tuhan. ${ }^{20}$

Hal ini dapat dilihat pada penerapan hukum pidana yang nota bene mengatur urusan publik yang didasarkan pada penerapan syari'ah akan mengesampingkan hak-hak warga negara non muslim. Contoh kasus yang ada dalam hukum perdata yaitu tentang kedudukan non muslim dalam sistem waris Islam yang ada diskriminasi terhadap non muslim dalam mendapatkan haknya sebagai saudara orang yang meninggal dunia. ${ }^{21}$

Urusan publik yang diatur berdasarkan syari'ah akan membawa konsekuensi terhadap hukum perdata. Konsepsi hukum publik pada masa awal islam memang tidak terlalu mementingkan kebut uhan klasifikasi hukum publik dan perdata, tetapi reformasi yang telah dilakukan terhadap penerapan syari'ah di beberapa di dunia muslim didasarkan pada reformasi, pertama, syari'ah lambat laun akan terabaikan dalam kehidupan sehari-hari seperti hukum dagang, hukum pidana dan lainnya. Kedua, dalam hukum keluarga yang dianggap sakral, sejumlah perubahan yang sangat signifikan

\footnotetext{
19 Muhyar Fanany, Abdullahi Ahmed an-Na'im: Paradigma Baru hukum Publik, dalam Pemikiran Kontemporer, 6-7

${ }^{20}$ Abdullahi Ahmed an-Na'im, Masa Depan Syari'ah: Sekularisme Dalam Prespektif Islam, dalam website http://www.law.emory.edu/cms/site/index/.php?id=2251.11 11 pebruari 2007

${ }^{21}$ Abdullahi Ahmed an-Na'im, Dekosntruksi syari'ah..., 337
} 
dengan jalan menginterpretasi dan menerapkan hukum keluarga itu. Kenyataan ini mendorong an-Na'im untuk mengkritisi berbagai kebijakan penerapan syari'ah khususnya hukum keluarga.

\section{METODOLOGI PEMBARUAN HUKUM ISLAM AN-NA’IM}

Salah satu fenomena yang dihadapi sebagian besar negara islam dalam kehidupan modern adalah persoalan mempertemukan islam dengan kehidupan modern. Persoalan yang sering kali muncul adalah bagaimana memposisikan Islam dan mendefinisikannya dalam fakta kehidupan dan masyarakat, yang mampu mengayomi seluruh warga negara dengan latar belakang suku dan agama yang heterogen, sesuai dengan tunt utan hukum modern dan prinsip-prinsip HAM.

Menanggapi hal di atas, an-Na'im menawarkan beberapa alternatif penyelesaian, diantaranya adalah merekonstruksi dan memperbarui syari'ah. Ini didasarkan atas asumsi bahwa syari'ah dalam beberapa aspek tertentu, sudah tidak memadai dan mendukung, bahkan bertentangan dengan norma-norma hukum modern dan standar HAM. Formulasi syari'ah yang membolehkan penggunaan kekerasan dalam menyebarkan islam, perbudakan dan perlakuan diskriminatif terhadap perempuan dan non muslim, disebut-sebut sebagai contoh kasus yang bertentangan dengan hukum modern dan HAM.

Syari'ah menurut an-Na'im adalah sebagai kegiatan yang secara intens dalam melaksanakan kewajiban keagamaan umat islam baik dalam pengertian personal, maupun dalam kaitannya dengan norma-norma dan kelembagaan sosial, politik, dan hukum. Namun prinsip-prinsip syari'ah bagi an-Na'im adalah hasil interpretasi manusia atas sumber hukum islam, yaitu al-Qur'an dan Sunnah, dan juga hasil interpretasi tersebut kemudian diamalkan dengan kurun waktu yang tidak lama, dalam artian masih ada ruang lingkup interpretasi yang dihasilkan atau dalam konteks tententu. ${ }^{22}$

Selain dari kedua sumber hukum di atas, ada beberapa sumber hukum islam yang perlu dikaji kembali sebagai jalan untuk mereformulasi syari'ah yang sesuai dengan

\footnotetext{
${ }^{22}$ Abdullahi Ahmed an-Na'im, Masa Depan Syari'ah: Sekularisme Dalam Prespektif Islam, dalam website http://www.law.emory.edu/cms/site/index/.php?id=2251.11
} 
deklarasi Universal HAM. diantaranya adalah Ijma', Qiyas, dan Ijtihad yang dianggap sebagai sumber syari'ah dalam catatan tradisi-tradisi awal.

\section{Al-Qur'an}

Al-Qur'an adalah sumber utama syari' ah yang diyakini umat islam secara literal dan final sebagai firman Allah. Bagi an-Na'im, al-Qur'an selain teks yang dianggap sangat akurat dan tidak perlu diperdebatkan, adalah sebagai hukum positif. Memahami peranan al-Qur'an dalam perumusan syari'ah adalah dengan mengapresiasi bahwa alQur'an terutama lebih berupaya membangun standar dasar perilaku umat islam ketimbang mengeskpresikan standar-standar itu sebagai hak dan kewajiban. ${ }^{23}$

Berdasar dengan asumsi di atas tujuan utama al-Qur'an seolah-olah bukan mengatur hubungan manusia dengan sesamanya, melainkan semata-mata hubungan manusia dengan Tuhannya. Jadi al-Qur'an bukanlah kumpulan hukum atau bahkan buku hukum, melainkan sesuatu yang memiliki daya tarik bagi manusia untuk mentaati hukum tuhan yang sudah lebih dahulu diwahyukan atau mungkin dapat ditemukan. ${ }^{24}$

Ayat yang mengandung hukum sebanyak 600 ayat yang terdapat di al-Qur'an dari jumlah ayat dalam al-Qur'an sebanyak 6.219 ayat, dan sebagian besar berkaitan dengan ibadah ritual. Dan 80 ayat yang mengunakan istilah hukum secara langsung dan jelas. Akhirnya, al-Qur'an dikesankan menjadi sumber keyakinan umat bahwa syari'ah adalah perintah langsung dan komprehensif dari Tuhan.

Contoh aturan-aturan detil al-Qur'an adalah tentang hukum keluarga dan waris. Terbatasnya referensi al-Qur'an dalam berbagai contoh selama periode awal mungkin semata-mata karena ulama atau ahli hukum tertentu tidak melihat ayat al-Qur'an yang sesuai dengan isu yang dekat dengan mereka. Dengan jalan ini, penggunaan al-Qur'an sebagai sumber syariah tergantung pada perbedaan-perbedaan pandangan tentang relevansi dan interpretasi ayat-ayat yang sedang diperbincangkan. ${ }^{25}$

Bagaimana pun, bagi an-Na'im dalam memposisikan al-Qur'an secara tepat adalah merupakan keharusan, sebab dengan mengetahui dimana ayat al-Qur'an tersebut diturunkan dan dengan kondisi seperti apa ayat al-Qur' an tersebut bicara. Oleh sebab itu

\footnotetext{
${ }^{23}$ Abdullahi ahmed an-Na'im, Dekosntruksi syari'ah..., 40

${ }^{24}$ Ibid, 41

${ }^{25}$ Ibid, 42
} 
an-Na'im yang pemikirannya tidak jauh beda dengan gurunya, Mahmud Muhammad Thaha, yang memetakan nas dengan dua prespektif. Pertama, al-Qur'an yang diturunkan di Makkah yang mempunyai nilai-nilai universal, yang menawarkan perlindungan HAM, semangat egaliter, dan demokratik. Ayat-ayat makkiyah merupakan pesan islam yang fundamental yang menekankan martabat yang inheren pada seluruh umat manusia tanpa membedakan jenis kelamin (gender), keyakinan keagamaan, ras dan sebagainya.

Kedua, al-Qur'an diturunkan di Madinah, dalam periode ini Islam menjadi sempit, spesifik, terbatas, yang dilegitimasi al-Qur'an untuk melakukan kekerasan, berkaitan dengan mempertahankan diri, melawan orang kafir, dakwah islam, dan perluasan wilayah, dan lebih-lebih pada masa ini ada pembedaan antara laki-laki dan perempuan, muslim dan non muslim. ${ }^{26}$

Sehingga kepentingan khusus pada konteks masa sekarang adalah mempertimbangkan kembali prinsip nasakh, yakni suatu metode unt uk mempertemukan ayat-ayat al-Qur'an yang dinilai bertentangan satu sama lain. Penting untuk ditegaskan, an-Na'im memahami nasakh seagai metode "evolusi syari'ah" yang memberikan kemungkinan memilah dan memilih ayat yang relevan untuk dipraktekkan pada kurun waktu tertentu, dan ayat-ayat mana yang dapat ditinggalkan atau harus ditangguhkan pemakaiannya.

Metode yang dielaborasi dari Mahmud Muhammad Thaha, guru an-Na'im ini berbeda dengan teori nasakh klasik, yang mengartikan nasakh sebagai upaya penghapusan ayat-ayat yang lebih awal, demi tujuan hukum oleh ayat-ayat dan sunnah masa berikutnya. ${ }^{27}$

Tegasnya, al-Qur'an pada ayat-ayat Madaniyyah menasakh ayat-ayat Makkiyah. Sementara menurut an-Na'im, ayat-ayat Makkiyah yang menasakh ayat-ayat Madaniyah. Sehingga yang diamalkan untuk keperluan sekarang (kecuali ibadah) adalah ayat-ayat Makkiyah.

2. Sunnah

Berasal dari kata sanna yang mempunyai arti menciptakan sesuatu dan memwujudkannya menjadi suatu model. Dalam konteks umat islam, sunnah adalah

\footnotetext{
${ }^{26}$ Mahmud Muhammad Thaha, Arus balik syari'ah, viii-ix

${ }^{27}$ Abdullahi ahmed an-Na'im, Dekosntruksi syari'ah..., 112
} 
segala sesuatu yang dapat dibuktikan sebagi praktek Nabi dan pengikutnya yang paling awal. ${ }^{28}$

Pengertian sunnah yang luas (sebagai tradisi individu terkemuka atau traidisi umat islam masa awal), tidaklah menyalahi keberadaan riwayat tingkah laku Nabi sejak masa-masa Islam yang paling awal. Karena sunnah Nabi memperoleh peranan utama sebagai sumber syari'ah selama abad II H, maka pastilah otentisitas dan berbagai keadaan asal-usulnya menjadi begitu penting. Oleh sebab itu para ulama mengembangkan kriteria atau perangkat yang sangat ketat untuk memverifikasi otentisitas khabar dan mengklasifikasikan sunnah sesuai dengan derajat kesahihan dan dapat diterima. Namun demikian, di era modern ini perangkat tersebut jika diukur secara logis, tidak menutup kemungkinan adanya lupa ingatan bagi orang yang meriwayatkan hadis tersebut, sehingga menimbulkan sunnah yang palsu. Oleh karena itu bagi an-Na'im upaya apapun untuk mengubah keaslian dari kepalsuan, atau mengembalikan sunnah yang tercemar sebelumnya adalah suatu tugas yang hampir-hampir mustahil dilakukan sekarang. ${ }^{29}$

\section{Ijma'}

Ijma' atau lebih dikenal dengan hasil konsensus para ulama' atau tradisi yang hidup para sahabat nabi dan generasi penerusnya, yang dijadikan sumber syari'ah yang ketiga. Dalam pemakaian ijma', ada pembenaran al-Qur'an dan sunnah yang mendukung atas diberlakukannya ijma' sebagai sumber syari'ah.

Selain al-Qur'an dan sunnah, ijma' juga mempunyai kekuatan besar dalam perkembangan syari'ah. Yakni interpretasi terhadap al-Qur'an dan sunnah dianggap benar apabila jika ia diakui secara konsesnsus (ijma'). ${ }^{30}$

Namun demikian bagi an-Na'im ada yang perlu dipertanyakan dalam prinsip ijma' sebagai sumber syari'ah. Karena ruang lingkup dan sifat ijma' yang tidak menutup kemungkinan adanya perbedaan. Kontroversi ini semua merupakan akibat dari tidak memadainnya perangkat metodologi yang mengantarkan umat islam kepada ijma' dalam berbagai masalah. Jawaban atas itu semuanya adalah; apakah ijma' didasarkan pada

\footnotetext{
${ }^{28}$ Ibid, 43

${ }^{29}$ Ibid, 47

${ }^{30}$ ibid
} 
prinsip kedaulatan rakyat atau atas dasar asumsi otoritas, kesalehan, dan moralitas agama. $^{31}$

\section{Qiyas}

Qiyas merupakan sumber syari'ah yang keempat. Dalam menerapkan qiyas, seorang ahli hukum menyimpulkan, dari prinsip yang telah dijadikan preseden, bahwa suatu kasus baru berada di bawah prinsip tersebut atau mirip dengan preseden ini berdasarkan kuatnya alasan ('illat). Semenjak pintu ijtihad tertutup, qiyas dijadikan alasan sebagai sumber syari'ah yang independen, karena keterkaitannya dengan ijtihad, yang merupakan salah satu dari teknik qiyas. ${ }^{32}$

\section{Ijtihad}

Ijtihad menurut bahasa adalah usaha yang keras dan gigih. Dalam pengertiannya lebih luas, ijtihad berarti penggunaan penalaran hukum secara independen untuk memberikan jawaban atas suatu masalah ketika al-Qur'an dan sunnah diam tak memberi jawaban. ${ }^{33}$

Jika demikian, ijma' dan qiyas dapat dikategorikan sebagai hasil ijtihad, karena dalam menyimpulkan hukumnya melalui penalaran atau interpretasi terhadap kedua sumber utama, al-Qur'an dan sunnah. Ijtihad sangat diperlukan dalam menginterpretasi al-Qur'an dan sunnah, karena tidak menutup kemungkinan teks tersebut mempunyai makna umum sehingga membutuhkan penalaran hukum.

Salah satu contoh ijtihad terhadap teks yang sudah jelas dan rinci,al-Qur'an ayat 6-10 surat ke-56, adalah penolakan Umar untuk membagikan tanah rampasan perang selama penaklukan di Irak dan Syiria sebagai bagian dari ghanimah (rampasan perang) kepada tentara muslim yang ikut campur. Karena selama Nabi hidup, beliau selalu membagikan harta rampasan tersebut sesuai dengan al-Qur'an. ${ }^{34}$

Dengan contoh tersebut bagi an-Na'im, ulama' kontemporer berhak melakukan ijtihad sekalipun menyangkut masalah yang sudah diatur oleh teks al-Qur'an dan sunnah

\footnotetext{
${ }^{31}$ Ibid, 48

${ }^{32}$ Ibid, 50

${ }^{33}$ Ibid, 53

${ }^{34}$ Ibid, 56
} 
secara rinci dan jelas, sepanjang hasil ijtihad itu sesuai dengan esensi tujuan risalah islam. ${ }^{35}$

Sehingga dari metode yang dikembangkan an-Na'im tersebut perlu adanya rekonstruksi syari'ah yang dibangun di atas empat kerangka yang berkaitan satu sama lain, yaitu:

Pertama, syari'ah merupakan produk sejarah. Cukup beralasan bagi an-Na'im bahwa syari'ah atau perundang-undangan, sejalan dengan perkembangan manusia. Oleh karena itu banyak hukum-hukum yang berkembang selama ini masih dalam konteks kesejarahan atau kehidupan dimana seorang pembuat hukum sendiri itu hidup atau sudah meninggal.

Kedua, syari'ah historis sudah tidak memadai. Dalam perkembangan fiqih islam diselimuti kontrovesi berkaitan dengan apakah pendapat dan keputusan yang didasarkan kepada nabi dan sahabat-sahabatnya itu asli atau hanya dibuat-buat. Sebab dalam setiap pengambilan dalil yang digunakan oleh semua madzhab selalu tidak lepas dari apa yang pernah disabdakan oleh Nabi, yang berupa sunnah.

Syari'ah sendiri merupakan jalan yang memberikan akses kepada sumber. ${ }^{36}$ Sehingga an-Na'im menyamakan syari'ah dengan fiqih, sebab keduanya merupakan hasil interpretasi yang dilakukan manusia yang bersumber kepada al-Qur'an dan sunnah. ${ }^{37}$

Sebagai hasil interpretasi, al-Qur' an dan sunnah tidak hanya terkungkung dalam periode yang menginterpretasi atas keduanya, melainkan keduanya harus dijadikan suatu pijakan yang dapat memberikan suatu bentuk yang koheren bagi semua manusia yang tanpa melanggar hak-hak asasi perempuan dan non muslim.

Ketiga, syari'ah Makkiyah adalah syari'ah modern. Di atas sudah sedikit disinggung bahwa al-Qur'an yang turun di Makkah merupakan ayat-ayat yang bersifat universal, yang tidak bertentang dengan HAM. Sedangkan ayat-ayat yang diturunkan di

\footnotetext{
${ }^{35}$ Ibid, 57

${ }^{36}$ Abdullahi Ahmed an-Na'im, al-Qur'an syari'ah dan HAM: kini dan di Masa Depan, Islamika No. 2 Oktober-Desember, 1993, 112

${ }^{37}$ Abdullahi Ahmed an-Na'im, Masa Depan Syari'ah: Sekularisme Dalam Prespektif Islam, dalam website http://www.law.emory.edu/cms/site/index/.php?id=2251.11
} 
madinah merupakan ayat-ayat yang diskriminatif bahkan bisa dikatakan sebagai ayat yang tidak manusiawi.

Menurut an-Na'im penyebab ulama atas tidak dipakainya ayat-ayat Makkiyah dalam kehidupan masyarakat adalah karena pada abad ke-7 kondisi riil masyarakat saat itu masih menuntut adanya pembangunan identitas bagi kaum muslimin dan kaum lakilaki dan juga berangkat dari asumsi yang telah mengakar pada saat itu. Untuk itu, Allah menurunkan ayat-ayat madinah yang dianggap lebih sesuai dengan realitas. Jadi adanya teks yang eksplisit yang menerangkan tentang pendiskriminasian terhadap non muslim dan kaum perempuan itu hanya merupakan tuntutan kondisi konkrit saat itu yang tidak mungkin dihindari. ${ }^{38}$

Oleh sebab itu ayat-ayat madaniyah yang turun ketika abad ke 7 itu hanya merupakan bentuk keterpaksaan sosial, karena ayat-ayat tersebut bukan merupakan tujuan ideal melainkan hanya bersifat temporal. Maka ayat-ayat Makkiyah menasakh terhadap ayat-ayat madaniyah, dan bukan sebaliknya, dikarenakan adanya perubahan waktu dan keadaan sosial yang menuntut untuk memberlakukan al-Qur' an sebagai suatu landasan universal.

Keempat, nasakh merupakan metodoloogi alternatif untuk membangun syari'ah modern. Sama dengan gurunya, Mahmud Muhammad Thaha, an-Na'im memposisikan nasakh bukan seperti yang selama ini para ulama atau mufassir memposisikan nasakh yaitu sebagai teori yang menghapus ayat-ayat sebelumnya, melainkan ayat-ayat yang sudah tidak relevanlah yang harus dinasakh. Seperti ayat-ayat Madaniyah yang dinasakh oleh ayat-ayat Makkiyah, yang merupakan ayat yang sesuai dengan prinsip egalitarian. ${ }^{39}$

Bagi an-Na'im, merekonstruksi syari'ah bukanlah perkerjaan haram, karena kesempurnaan syari'ah pada kemungkinannya untuk terus berkembang dan fungsional bagi kehidupan.

Syari' ah yang ada saat ini, menurutnya lebih atas al-Qur' an periode Madinah dari pada ayat-ayat yang turun pada masa Makkiyah. Melalui al-Qur'an periode Madinah inilah, berikutnya sunnah yang menyertainnya, syari'ah mulai membedakan status hukum antara muslim dan non muslim.

\footnotetext{
${ }^{38}$ Muhyar Fanany, Abdullahi Ahmed An-Nai'im: Paradigma Baru Hukum Publik...., 11

${ }^{39}$ Mahmud Muhammad Thah, Arus Balik Syari'ah, ix
} 
Karenanya, an-Na'im menilai perlu merekonstruksi syari'ah dengan membalikkahn proses nasakh (penghapusan hukum suatu teks) sehingga teks-teks yang dihapus pada masa lalu dapat digunakan dalam hukum sekarang dengan konsekuensi penghapusan teks yang dulu digunakan sebagai basis syari'ah. Ayat-ayat digunakan sebagai basis syari'ah dicabut dan ayat-ayat yang dulu dicabut, digunakan sebagai basis hukum modern. Apabila diterima, maka an-Na'im optimis keseluruhan produk hukumnya akan sama Islaminya dengan syari' ah yang ada selama ini. ${ }^{40}$

\section{PEMIKIRAN AN-NA'IM TENTANG KEDUDUKAN NON MUSLIM DALM KEWARISAN ISLAM}

An-Na'im menolak dengan tegas apa yang menjadi prinsip syari'ah selama ini yang masih memberikan peluang untuk adanya diskriminasi yang bersumber dari agama maupun kelamin. ${ }^{41}$

Dengan adanya diskriminasi tersebut sudah barang tentu yang ada dalam prinsip syari'ah adalah pembedaan terhadap keyakinan antara orang muslim dengan non msulim, padahal dalam realitanya, Islam maupun kristen adalah agama global dengan misi universal, yang mengajak manusia untuk menyembah kepada Allah SWT. ${ }^{42}$

Di antara pendiskriminasian yang dimaksud an-Na'im yang bertentang dengan HAM adalah tidak dapatnya seorang non muslim dalam mendapatkan warisan dari keluarga yang muslim, ataupun sebaliknya, seorang muslim tidak dapat menerima warisan dari keluarga yang non muslim.

Perbedaan agama yang merupakan penghalang utama, perlu dikemukakan bahwa aturan ini menimbulkan banyak kesulitan di wilayah-wilayah karena yang anggota keluarganya menganut berbagai macam agama, karena bila seorang muslim meninggal dunia semua sanak keluarga yang non muslim akan disisihkan dari ahli waris, sedangkan orang non muslim yang meningga dunia, sanak keluarganya yang muslim akan menerima warisan. ${ }^{43}$

\footnotetext{
${ }^{40}$ Abdullahi ahmed an-Na'im, Dekosntruksi syari'ah..., 10

${ }^{41}$ Charles Kurzman, Wacana islam Liberal: pemikiran Islam kontemporer .... 387

42 John L. Esposito, Islam Aktual, 73

${ }^{43}$ J.N.D. Anderson, Hukum Islam di Dunia Modern, 85
} 
Meski al-Qur'an dan sunnah yang sudah menjelaskan dengan jelas dan rinci tentang pembagian warisan, namun bagi an-Na'im al-Qur'an dan sunnah tersebut terbentuk di Madinah, pada masa Nabi hijrah ke Madinah, di tempat inilah kaidahkaidah hukum terbentuk. Oleh sebab itu al-Qur'an maupun sunnah yang mengandung tentang kewarisan jelas bertentangan dengan semangat ayat yang diturunkan di makkah, yang mengusung misi universal, egalitarian, dan tanpa ada diskriminasi.

Jelas ayat yang turun di madinah merupakan bentuk pelanggaran HAM yang ada dalam sistem kewarisan Islam. Sebagai seorang reformis hukum islam, an-Na'im memposisikan prinsip-prinsip HAM yang dideklarasikan pada tahun 1948 sebagai acuan dalam mengkritik terhadap ketentuan syari'ah yang telah menyimpang dari tujuan awalnya, yaitu kemaslahatan umat manusia.

Posisi syari' ah yang sudak dikenal dalam terminologi modern sebagai Hak Asasi Manusia juga dibenarkan oleh konteks hitoris. Sebagai contoh, status hak seorang berdasarkan agamanya. Begitu pula, syari'ah yang membatasi hak-hak asasi manusia dibenarkan oleh konteks sejarah.

Dengan demikian menurut an-Na'im syari'ah yang merupakan sistem hukum yang praktis, maka Hak-Hak Asasi Manusia yang berlaku tidak dapat disampingkan lagi seperti penggunaannya pada abad kedelapan. ${ }^{44}$

Sebagai bentuk perlindungan hak setiap warga negara, an-Na'im menawarkan prinsip reporisitas universal, yang dikenal dengan istilah "golden rule" yang artinya dalam mengklaim dan menggunakan hak-hak perorangan dan kolektif untuk menentukan nasib sendiri, kaum muslimin juga harus mengakui dan menjamin hak-hak yang sama bagi orang lain. ${ }^{45}$

Bentuk perlindungan hak yang harus dilakukan adalah menyertakan di depan hukum terhadap non muslim atau perempuan. Sebab tidaklah cukup apabila menjamin hak asasi manusia berdasarkan pada tingkat hukum jika hanya mengandalkan panggilan manusia semata tetapi menghiraukan nilai-nilai universal. ${ }^{46}$

\footnotetext{
${ }^{44}$ Abdullahi ahmed an-Na'im, Dekosntruksi syari'ah..., 326

45 Ridwan al-Makassary, Civil Rights, kajian konseptual dan Dilemanya di Indonesia, www.sinarharapan.co.id/berita/0401/10/feal01.html

${ }^{46}$ M. Arkoun, Rethingkin Islam, 191
} 
Seperti diisyaratkan di atas, salah satu bentuk dari keterkaitan antara syari'ah dan pelanggaran HAM adalah aplikasi syari'ah yang sebelumnya sebagai hukum personal bagi kaum muslim, termasuk hukum waris. Dalam hal ini yang menjadi sasaran adalah seorang non muslim yang biasanya disebut sebagai Dzimmih.

Tidak didapatkannya harta warisan dari keluarga muslim, merupakan bentuk diskriminasi secara agama, oleh karena itu bagi an-Na'im, merupakan suatu keharusan untuk memposisikan Deklarasi HAM Universal sebagai pedoman dalam setiap hidup bernegara. Dan juga mengembalikan prinsip nasakh sebagai bentuk penghapusan ayat Makkiyah terhadap ayat Madaniyah. Pendiskriminasian atas dasar agama ini, telah dibangun dengan berbagai sebab yang besar dari konflik dan perang internasional karena negara-negara tersebut setuju dengan minoritas non muslim yang tersiksa. Bagi anNa'im yang terpenting adalah pendiskriminasian yang berdasarkan gender maupun agama secara moral tertolak dan secara politik tidak dapat diterima sekarang. ${ }^{47}$

\section{ANALISIS TERHADAP METODOLOGI PEMBARUAN HUKUM ISLAM AN- NA'IM}

Dalam pembahasan di atas, telah dijelaskan bahwa metodologi yang digunakan an-Na'im sebelum mereformulasikan syari'ah adalah dengan memberikan pengertian baginya tentang sumber-sumber hukum syari'ah yang antara lain al-Qur'an, sunnah, ijma', qiyas, dan ijtihad. Kelima sumber tersebut juga telah dijadikan oleh para ulama terdahulu dalam menetapkan hukum waris.

Dengan memandang al-Qur'an sebagai sumber utama syari'ah islam, maka anNa'im membagi al-Qur'an dengan dua perspektif, yaitu apa yang sama dengan metodologi yang dipakai oleh gurunya, yaitu Mahmud Muhammad Thaha, yang membedakan antara ayat-ayat Madaniyah dengan ayat-ayat Makkiyah. Dari ayat-ayat tersebut, yang menurut ulama klasik ada penghapusan hukum di antaranya, ayat yang turun di madinah telah menasakh ayat yang turun di makkah. Namun bagi an-Na'im teori yang selama ini berkembang itu memerlukan adanya rekonstruksi untuk menemukan formulasi syari'ah yang tepat, sesuai dengan konteks kekinian.

\footnotetext{
${ }^{47}$ Abdullahi ahmed an-Na'im, Dekosntruksi syari'ah..., 340
} 
Dengan alasan demikian an-Na'im telah secara universal mengganggap (hukum) ayat Makkiyah telah menasakh (hukum) ayat Madaniyah, hal seperti ini cukup meragukan, sebab ayat Makkiyah yang turun sebelum ayat Madaniyah, secara tidak langsung ayat Madaniyah telah menasakh ayat Makkiyah yang secara hukumnya berbeda, dan secara ruang lingkup atau sebab turunnya ayat tersebut berbeda pula.

Ayat-ayat yang turun di Makkah, semenjak diutusnya nabi Muhammad, kaum muslimin masih sedikit. Hal ini menyebabkan ayat-ayat Makkiyah selalu berkenaan dengan pembelaan terhadap yang minoritas, yakni orang-orang Islam, yang isinya pemberantasan terhadap sikap permusuhan dan saling menghancurkan keyakinan serta menolak hal-hal yang subhat dan khurafat. Dalam budaya orang jahiliyah, mereka masih mempunyai watak yang keras, sehingga ayat-ayat yang turun pada saat itu secara tidak langsung dengan tujuan menundukkan mereka, yang kemudian mereka diajak masuk islam. ${ }^{48}$

Setelah Nabi berdakwah di Makkah, kemudian beliau hijrah ke Madinah. Di tempat inilah ayat-ayat yang diturunkan Allah kepada nabi-Nya yang berkenaan dengan hukum-hukum agama, kaidah-kaidah menggerakkan masyarakat, dan meletakkan dasardasar kekuasaan. ${ }^{49}$

Di antara ayat-ayat yang berkenaan dengan hukum-hukum agama adalah ayat tentang pembagian waris, yang tercantum dalam al-Qur' an surat an-Nisa' ayat 1, 7, 8, $9,11,12,33$, dan 176 juga dalam surat al-Anfal ayat 75. Dalam ayat-ayat tersebut Allah menjelaskan secara gamblang tentang pembagian harta waris kepada ahli warisnya.

Ayat-ayat di atas dijadikan ulama sebagai landasan dalam menetapkan hukum dalam kewarisan islam. Dalam menafsirkan ayat-ayat tersebut, para ulama' sepakat bahwa tidak adanya penasakhan terhadap ayat-ayat tersebut. Sebagaimana anggapan anNa'im bawah ayat-ayat tersebut sudah tidak relevan lagi, karena adanya diskriminasi terhadap orang-orang non muslim.

Dengan apa yang menurut an-Na'im ijtihad yang dilakukannya merupakan bentuk kesamaan dengan apa yang dilakukan oleh Umar ketika menolak pembagian

\footnotetext{
${ }^{48}$ Fahd bin Abdirrahman Ar-Rumi, Ulumul Qur'an, Studi Kompleksitas Al-Qur'an, terj. Amirul hasan, 163-164

${ }^{49}$ Ibid, 164
} 
harta rampasan kepada para tentaranya. Meski apa yang dilakukan an-Na'im dalam usaha menghilangkan pendiskriminasian adalah perbuatan yang baik, tapi kita juga harus melihat bahwa ada perbedaan yang mendasar yaitu jika yang dilakukan oleh umar adalah karena kesejahteraan rakyatnya, tapi yang dilakukan an-Na'im adalah hanya semata untuk kaum muslim untuk berbuat toleran kepada agama lain, tapi bukan untuk yang bersifat prinsipil seperti pembagian harta warisan kepada orang yang berbeda agama, begitu sebaliknya.

Latar belakang pemikiran an-Na'im, terlihat banyak pokok-pokok pikiran yang diperdebedatkan, diantaranya adalah masalah kritiknya terhadap syari'ah historis, yang mana ia mengatakan bahwa produk hukum yang sudah jadi, seperti halnya fiqih, merupakan interpretasi manusia yang tidak menutup kemungkinan adanya kesalahankesalahan yang juga masih membutuhkan interpretasi terhadap sumber-sumber hukum islam. ${ }^{50}$ Hal yang semacam ini memang wajar dalam setiap perkembangan keilmuan di dunia. Tapi pemikiran an-Na'im tersebut tidak bisa diterima begitu saja, sebab syari'ah bukanlah standar hukum yang berlaku secara monolitik, tetapi syari'ah ada sesuai dengan kondisi dimana syari'ah tersebut dihasilkan. ${ }^{51}$ Hal yang semacam ini sesuai dengan kaidah ushul fiqih yang mentakan;

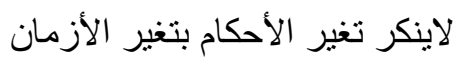

"tidak dapat dipungkiri perubahan hukum disebabkan peruahan zaman".

Landasan dalam setiap kritiknya adalah kembali kepada ayat-ayat Makkiyah yang menurut an-Na'im adalah ayat-ayat yang mengandung universalisme, kebebasan berkeyakinan, beragama dan kesetaraan. Menurut sudut pandang religius hal yang semacam itu tidak akan bisa bersifat netral antara keyakinan kepada Allah dan ketidakberimanan. Sebab dalam al-Qur' an sudah dijelaskan dalam ayat 98:7 yang artinya sebagai berikut: "orang-orang yang tidak beriman di antara ahlu al-kitab dan kaum penyembah berhala akan dibakar selama-lamanya di neraka. Mereka adalah seburukburuk makhluk". 52

\footnotetext{
${ }^{50}$ Abdullahi Ahmed An-Na'im, Masa Depan Syari'ah....,

${ }^{51}$ Hasan Abdullahi al-Turabi, Kasus Populisme Islam Sudan; Gelombang Kedua Kebangkitan Islam, islamika, no. 6.

52 Ishtiaq Ahmed, Konstitusionalisme, HAM dan Reformasi Islam, dalam dekonsruksi Syari'ah II, kritik konsep, penjelajahan lain, terj. Farid wajidi, 77
} 
Semua umat muslim yakin bahwa al-Qur'an adalah kitab Allah yang diturukan kepada Nabi Muhammad. Sehingga tidak adanya rasa curiga terhadap kebenaran alQur'an adalah hal yang mutlak. Tapi bagi an-Na'im yang terpenting dalam kajiannya adalah memposisikan al-Qur'an dalam dua bentuk yang berbeda, sebagaimana yang dijelaskan di atas. Tapi yang perlu digaris bawahi adalah pesan-pesan yang diturunkan kepada nabi tersebut tidaklah terdapat diskontinuitas terhadap ayat yang satu dengan ayat lainnya. ${ }^{53}$ Sebab jika terjadi benturan ayat maka tidak mungkin Tuhan akan menciptakan sesuatu yang sama.

An-Na'im yang jalan keilmuannya banyak mengambil dari dunia barat, lebihlebih keadaan Negara sudan yang dijadikan an-Na'im dalam menilai perlunya merekonstruksi syari'ah tersebut. Dalam setiap kehidupan seseorang pastilah tidak akan terlepas dengan pengaruh sosio-kultur tempat seseorang tersebut berdiam. An-Na'im yang banyak menimba ilmu dari dunia barat juga tidak bisa terlepas dari pemikiranpemikiran yang berkembang di dunia tersebut, sehingga apa yang dijadikan an-Na'im dalam menilai syari'ah adalah bentuk kekecewaan terhadap hukum-hukum yang bersumber dari syari'ah dijadikan legitimasi dalam hukum Negara.

Hal yang di atas memicu an-Na'im untuk bergerak, sebagai orang yang membela kepentingan HAM, hukum-hukum yang bersumber dari syari'ah dikatakan sudah tidak relevan lagi.

Meskipun demikian, bagi Arkoun tidaklah mudah untuk mencampur adukkan antara agama dan negara. Sebab jika yang demikian dilakukan maka hal yang terburuk akan terjadi, yaitu ketidak adanya orisinalitas terhadap karya ilmiah. Adanya intervensi negara terhadap agama disebabkan adanya interpretasi terhadap jalannya liberalisasi di dunia barat dari orang-orang muslim yang pemikirannya masih dangkal. ${ }^{54}$ Sehingga hal ini menyebabkan orang-orang islam beramai-ramai dalam mengkaji ulang syari'ah yang dituntut sesuai dengan konteks kekinian, salah satunya adalah an-Na'im.

\footnotetext{
${ }^{53}$ M. Quraish Shihab, Membumikan al-Qur'an, 143. Lihat juga Mahmud Arif, Wacana Nasakh dalm tafsir fi dilal al-Qur'an, dalam studi al-Qur'an Kontemporer, 109

${ }^{54}$ M. Arkoun, Rethinking Islam, xvi
} 


\section{ANALISI TERHADAP PEMIKIRAN AN-NA'IM TENTANG KEDUDUKAN NON MUSLIM DALAM KEWARISAN ISLAM}

Hadis Nabi SAW menjelaskan bahwa salah satu penghalang dalam mendapatkan bagian waris adalah berlainnya agama ahli waris dengan pewaris. Tapi bagi an-Na'im itu merupakan diskriminasi terhadap hak-hak seorang yang pastinya mendapatkan harta warisan.

Hadis tersebut dari Rasulullah SAW yang diriwayatkan oleh Bukhori, Muslim, Dawud, al-Tirmidi, dan Ibn majjah.

$$
\text { لا يرث المسلم الكافر و لا الكافر المسلم }
$$

"seorang muslim tidak boleh mewarisi orang kafir, dan orang kafir tidak boleh mewarisi orang muslim."

Para ulama' sepakat bahwa penghalang utama dalam pembagian harta waris adalah perbedaan agama. Sebab dalam al-Qur'an sendiri sudah membedakan antara orang yang beriman dan tidak, sehingga timbul pertanyaan, apa yang dijadikan landasan an-Na'im dalam menetapkan bagian waris bagi orang non muslim?.

Bagi an-Na'im hadis di atas terdapat sikap diskriminatif, yaitu tidak mendapatkannya ahli waris non muslim dari keluarga yang muslim, begitu juga sebaliknya, hal yang seperti ini perlu dihapus, sebab hadis ini bertentangan dengan semangat egalitarian, HAM, kesamaan derajat dalm hukum. ${ }^{55}$

Dalam penjelasannya, Deklarasi Hak Asasi Manusia (HAM) yang dilaksanakan pada tahun 1948 tersebut dijadikan pijakan dalam menghilangkan diskriminasi terhadap orang non muslim dari orang-orang muslim. Sehingga tidak heran bila pemikiran anNa'im cenderung ke sistem yang digunakan oleh orang-orang barat dari pada sistem yang digunakan oleh orang-orang islam sebagai landasan hidupnya.

Padahal Hak Asasi Manusia (HAM) sesungguhnya ada sejak manusia dilahirkan. ${ }^{56}$ Dan kesadaran atas hak-hak asasi manusia telah muncul sejak lama. Diantara contoh adanya HAM pada masa dulu adalah zaman plato (428-348 SM) dan Aristoteles (148-322 SM) yang memaklumkan warganya bahwa kesejahteraan bersama

\footnotetext{
${ }^{55}$ Abdullahi Ahmed an-Na'im, Dekonstruksi Syari'ah....., 339

${ }^{56}$ Cholil Nafis, Fiqih HAM, dalam Fiqih Progresif, 144
} 
baru tercipta apabila setiap individu telah melaksanakan hak dan kewajiban masingmasing.

Deklarasi HAM pada tahun 1948 merupakan sarat dengan nilai politik sebab ketika terbentuknya deklarasi tersebut agama dijadikan yang kedua dibawah akal manusia, oleh karena itu deklarasi tersebut lahir di dunia barat maka yang dijadikan acuan adalah system liberal, yang mana system ini menganut pada pelepasan nilai-nilai agama dan menganggap otoritas sepenuhnya ada di tangan manusia tanpa mengikut sertakan kedaulatan Tuhan. ${ }^{57}$

Landasan yang demikian telah dipakai an-Na'im dalam setiap pengkritikan terhadap apa yang ada di Syari'ah yang dinilai diskriminatif, maka deklarasi HAM yang dibangun di barat tersebut dijadikan alasan untuk melegitimasi pemikirannya.

Hal yang semacam ini dalam ilmu filsafat dikatakan sebagai aliran modern, yang mana salah satu cirinya adalah meletakkan kekuatan akal manusia di atas segalagalanya. Karena ilmu yang berkembang di barat adalah menjadikan alam sebagai suatu tujuan dalam perkembangan keilmuannya, sehingga hal ini melupakan manusia terhadap apa yang melatar belakangi terjadinya alam semesta. ${ }^{58}$

Dalam kehidupan umat islam sendiri, perbedaan antara muslim dan non muslim juga dilakukan oleh al-Qur'an, yaitu pada surat al-Kafirun ayat 4-6, yang artinya; "dan aku tidak pernah menjadi penyembah apa yang kamu sembah. Dan tidak pernah (pula) menjadi penyembah Tuhan yang aku sembah. Untukmulah agamamu, dan untukkulah agamaku."

Dalan surat lainnya, al-Baqarah 256, artinya:

"tidak ada paksaan untuk (memasuki) agama (islam), sesungguhnya telah jelas jalan yang benar daripada jalan yang sesat. Karena itu barang siapa yang ingkar kepada Thaghut dan beriman kepada Allah, maka sesungguhnya ia telah berpegang kepada buhul tali yang amat kuat yang tidak akan putus. Dan Allah maha mendengar lagi Maha mengetahui."

\footnotetext{
${ }^{57}$ Ibid, 151

${ }^{58}$ Huston Smith, Kebenaran Yang Terlupakan, xxi
} 
Pada era modern seperti sekarang ini banyak pemikiran-pemikiran yang mengedepankan pluralitas. Tujuan dari ide seperti ini adalah agar terciptanya perdamaian dan toleran antar agama. Tapi hal yang semacam ini masih dalam runag lingkup sosial, bukan dalam tataran ideologi, seperti pendiskriminasian mendapatkan warisan atas nama agama.

Usaha ijtihad yang dilakukan an-Na'im dalam menghilangkan diskriminasi atas nama agama, terbentur dengan latar belakang kehidupannya yang banyak terisnpirasi dari pemikiran barat yang mengakibatkan terjadinya pemisahan antara agama dengan individu atau Negara. Padahal apa yang terhadi dalam pengijtihadan yang dilakukan oleh para ulama adalah tidak lepas dari agama atau syari'ah.

Dengan landasan pemikiran yang seperti itu anggapan an-na'im terhadap adanya diskriminasi terhadap orang non muslim perlu diperjuangkan. Dan penghapusan sistem kewarisan islam yang salah satu penghalang dalam mendapatkan warisan adalah berbedanya agama.

An-Na'im menolak sunnah sebagai landasan dalam penghalang utama bagian warisan bagi non muslim karena ia sendiri masih mempertanyakan originalitas sunnah sendiri. Tapi yang perlu digaris bawahi bahwa fungsi sunnah Nabi Muhammad adalah sebagai penjelas terhadap maksud firman-firman Allah. ${ }^{59}$

Dalam hukum islam kedudukan akal hanya terletak di bawah sumber hukum yang utama yaitu al-Qur'an dan sunnah. Setelah itu ulama' menyepakati adanya ijma' sebagai konsensus kesepakatan yang dilakukan ulama'. Tapi di tempat yang ketika ini masih banyak yang memperdebatkan, sebab ada yang berpendapat bahwa setelah al-Qur'an dan sunnah adalah akal atau ra'yu. Pendapat ini seperti yang diungkapkan oleh Mahmud Syaltut dalam menetapkan hukum islam atau setiap mengeluarkan fatwanya. ${ }^{60}$

Akal sendiri menurut islam tidak ada kontradiksi dengan al-Qur'an dan sunnah, jika terjadi, maka mustahil islam akan menjadikan kedudukan akal sejajar dengan kedudukan keduanya, sebagaimana agama-agama lainnya yang mengatakan "agama berada di atas akal. Akal tidak berhak turut campur dalam urusan-urusan agama."61

\footnotetext{
${ }^{59}$ M. Quraish Shihab, membumikan al-Qur'an, 122

${ }^{60}$ Abd. Salam Arief, Pembaruan Pemikiran Hukum Islam Antara Fakta Dan Realita. 182

${ }^{61}$ Murtadha Muthahari, Islam Dan Tantangan Zaman, 306
} 
Oleh karena itu benar bila an-Na'im mencoba memisahkan antara agama dengan Negara, sebab Negara merupakan bentuk dari akal manusia, sedangkan agama adalah berasal dari fitrah manusia. Bagi an-Na'im yang ada di Sudan merupakan intervensi yang dilakukan oleh pemerintah dalam pembentukan hukum-hukum Negara terlewat batas, sebab tidak ada perbedaan bagi setiap warga Negara yang melakukan tindak pidana, maka orang tersebut di hukum dengan cara hukum yang bersumber dari syari'ah. Maka an-Na'im tidak sepakat dengan hal tersebut.

Hal yang terpenting dalam pembahasan ini adalah kedudukan non muslim dalam kewarisan islam memang tidak dapat dirubah, sebab hal yang menjadi penghalang adalah masalah prinsip setiap manusia. Dan sumber sunnah pun sudah cukup dijadikan rujukan apabila sunnah tersebut benar-benar mutawattir.

\section{PENUTUP}

Dari pembahasan tentang pemikiran an-Na'im di atas, nampak sekali adanya pro dan kontra, namun demikian pemikiran an-Na'im patut dihargai, karena merupakan suatu upaya untuk menghadirkan tatanan yang dilandasi oleh norma-norma dan tata nilai Islam dalam kehidupan kontemporer. Hal ini secara jelas menunjukkan kepedulian anNa'im terhadap kelangsungan penerapan nilai-nilai Islam berhadapan dengan tuntutan modernisasi.

Kajian yang menjadi konsen an-Na'im yaitu isu syariat versus HAM dilihat dari epistimologinya dapat dikelompokkan kajian yang liberal karena kerangka metodologi yang dipakai seperti kaidah yang umum digunakan oleh kaum sekuler. Keabsahan rasional dan saintifik dijadikan ukuran menentukan kebenaran dan nilai kemanusiaan dijadikan tujuan dengan mengesampingkan nilai ketuhanan. Bahkan an-Na'im menafikan peran sumber hukum Islam yang utama yaitu Alquran dan Hadis. Hal ini terlihat jelas pada sikapnya yang cenderung mengabaikan peran penting dari syariat tentang HAM tapi di sisi lain peran hukum sekuler dianggap begitu dominan dan "hebat"dalam memecahkan persoalan HAM internasional. Terutama kasus non muslim dalam kewarisan islam.

Simpulan an-Na'im yang menyatakan bahwa persoalan HAM yang melanda dunia tidak bisa dipecahkan oleh syariat tapi hanya dapat dipecahkan oleh hukum 
sekuler, menurut penulis merupakan sebuah kesimpulan yang bersifat subyektivitas yang tidak bisa diterima secara apriori.

Satu sisi yang belum tampak ialah tindak lanjut pemikiran an-Na'im ketika menyentuh wilayah operasionalisasi, karena pemikiran al-Na'im dilatarbelakangi oleh pencermatan pada kasus-kasus di negaranya dan negara-negara tetangganya yang berlabel Islam berhadapan dengan permasalahan modernitas yang ia lihat selama menjalani studi di negara barat. Apakah ide-ide an-Na'im bisa ditindaklanjuti secara nyata di negara-negara yang tidak berlabel Islam, dengan mayoritas penduduknya beragama Islam, atau bahkan dalam kondisi negara yang hanya memiliki separuh atau sebagian kecil penduduk yang beragama Islam merupakan pertanyaan yang masih harus dijawab oleh semua orang yang memiliki kepedulian pada pembaharuan hukum Islam baik dari sisi teoritis maupun praktisnya.

Dengan demikian, dapat dikatakan bahwa pemikiran an-Na'im belum final dan masih menyisahkan bidang garapan kepada umat. Semua ide pemikiran an-Na'im tersebut semestinya disikapi secara kritis dan perlu analisis historis yang objektif sehingga tidak terjadi distorsi peran syariat terhadap HAM seperti dituduhkan.

\section{DAFTAR PUSTAKA}

Abdullahi Ahmed An-Na'im, Dekonstruksi Syari'ah Wacana Kebebasan Sipil, Hak Asasi Manusia dan Hubungan Internasional dalam Islam, terj. Ahmad Suaedy, (Yogyakarta: LkiS, 1996)

Abdullahi Ahmed an-Na'im, al-Qur'an syari'ah dan HAM: kini dan di Masa Depan, Islamika No. 2 Oktober-Desember, 1993

Bassam Tibi, Syari'ah, HAM, dan hukum Internasional, dalam Demokrasi Syari'ah II; Kritik Konsep Penjelajahan Lain, terj. Farid Wajidi, (Yogyakarta: LkiS, 1996) Charles Kruzman, Syari'ah dan Isu-Isu HAM, dalam Wacana Islam Liberal : Pemikiran Islam Kontemporer Tentang Isu-Isu Global, Terj. Bahrul Ulum, (Jakarta; Paramadina, 2001)

Fahd bin Abdirrahman Ar-Rumi, Ulumul Qur'an, Studi Kompleksitas Al-Qur'an, terj. Amirul hasan, 
Harun Nasution dan Bahtiar Effendi (ed), Hak-Hak Asasi Manusia dalam Islam, ( Jakarta: Pustaka Firdaus, 1995)

Hasan Abdullahi al-Turabi, Kasus Populisme Islam Sudan; Gelombang Kedua Kebangkitan Islam, islamika

Imam Muslim, Sahih Muslim, Juz 11

Ishtiaq Ahmed, Konstitusionalisme, HAM dan Reformasi Islam, dalam dekonsruksi Syari'ah II, kritik konsep, penjelajahan lain, terj. Farid wajidi

James W. Nickel, Hak Asasi Manusia: Releksi Filosofis Atas Deklarasi Universal Hak Asasi Manusia, terj. Titis Eddy Arini, (Jakarta: PT. Gramedia Pustaka Utama, 1996)

John L. Esposito, The Oxford Encyclopedia Of The Modern Islamic World, Vol. IV,ed (New York: Oxford University Press, 1996)

John L. Esposito, Islam Aktual, terj. Norma Arbi’a Juli Setiawan, (Jakarta: Inisiasi Press, 2005)

John L. Esposito, Tokoh Kunci Gerakan Islam Kontemporer, terj. Sugeng Hariyanto, dkk, ( Jakarta: PT. Raja Grafindo Persada, 2002)

J.N.D. Anderson, Hukum Islam di Dunia Modern, terj. Machnun Husein, (Yogyakarta: PT. Tiara Wacana Yogya, 1994)

M. Arkoun, Rethingkin Islam, terj. Yudian W. Asmin, (Yogyalarta: LPMi, 1996)

Mahmud Muhammad Thaha, Arus Balik Syari'ah, terj. Khairon Nadhiyin, (Yogyakarta: LkiS, 2003)

Muhyar Fanani, Abdullahi Ahmed an-Na'im: Paradigma Baru Hukum Publik, Dalam Pemikiran Kontemporer, (Yogyakarta: Jendela, 2003)

Maulana Abul A'la Maududi, Hak-Hak Asasi Manusia Dalam Islam, terj, Bambang Iriana Djaja atmadja, (Jakarta; Bumi Aksara, 2005)

M. Quraish Shihab, Membumikan al-Qur'an, 143. Lihat juga Mahmud Arif, Wacana Nasakh dalm tafsir fi dilal al-Qur'an, dalam studi al-Qur'an Kontemporer, (Bandung: Mizan, 1994)

Ridwan al-Makassary, Civil Rights, kajian konseptual dan Dilemanya di Indonesia, www.sinarharapan.co.id/berita/0401/10/feal01.html 